components. Features of the US system of language teacher preparation that promote its coherence and dialectical interconnectivity are openness, dynamism, purposefulness, adaptability and decentralization. The system's integrative elements are the goals and objectives of teacher preparation, the content and purpose of the university course of study, forms of organization of the processes of education and professional development, approaches to the professional competence development, didactic principles, means and ways of obtaining higher education, the educational process and its results. The underlying principles of foreign language teacher preparation are diversity and inclusion, lifelong learning, personalization together with related to it individualization and differentiation, standardization, fundamentalization, the spread of information technologies in education, collaboration, autonomy, academic integrity, academic mobility, competition and others.

Key words system of foreign language teacher education, university, teacher candidate, educational program, foreign language education, USA.

удк 378.091.2:615.83(477+71) (045)

Інна Мордвінова

Сумський державний університет ORDCID ID 0000-0002-0759-0360

Аліна Ольховик

Сумський державний університет ORDCID ID 0000-0003-0114-1190 DOI 10.24139/2312-5993/2020.02/276-285

\title{
ПОРІВНЯЛЬНА ХАРАКТЕРИСТИКА СИСТЕМИ ПІДГОТОВКИ БАКАЛАВРІВ СПЕЦІАЛЬНОСТІ «ФІЗИЧНА ТЕРАПІЯ В УКРАЇНІ ТА КАНАДІ
}

у статті висвітлено професійну підготовку бакалаврів «фізичної терапії» в Україні та Канаді. Дана спеціальність вимагає від майбутніх спеціалістів комплексного підходу під час здійснення своєї професійної діяльності. Спеціаліст із фізичної терапії повинен компетентно вміти проводити фізіотерапевтичне обстеження, здійснювати аналіз отриманих даних, установлювати фізіотерапевтичний діагноз, проводити фізіотерапевтичні заходи й оцінку їх ефрективності, працювати в мультидисииплінарній команді. Доведено, що вітчизняна модель підготовки має відмінності від канадської моделі, що грунтуються на принципах організації, фінансування, професійного етикету, самодисципліни спеціалістів на відміну від канадської, де за основу взято мультидисциплінарний підхід.

Ключові слова: фізична терапія, студент, програми, професійна підготовка, фізіотерапевтична діяльність, мультидисциплінарний підхід.

Постановка проблеми. В епоху глобальної соціальної, економічної та демографічної кризи особливо актуальним $€$ питання щодо рівня здоров'я населення, його збереження й покращення, що на даний час $€$ медикосоціальною проблемою, яка вимагає негайного вирішення. У сучасному житті виникає потреба в удосконаленні організації вітчизняної системи підготовки майбутніх спеціалістів з фізичної терапії.

Головними проблемами підготовки спеціалістів даної професії на теперішній час $€$ відсутність на державному рівні освітніх стандартів підготовки та можливості працевлаштування в закладах охорони здоров'я (Приступа, 2011, с. 92-96). 
На сьогодні виникає необхідність у фундаментальній переорієнтації вітчизняних навчальних планів і програм із підготовки фахівців із фізичної терапії з урахуванням закордонного досвіду. Значної модернізації потребує українська система професійної підготовки майбутніх бакалаврів з фізичної терапії з урахування міжнародного досвіду, одночасно враховуючи вітчизняні традиції (Лянной, 2017, с. 38-40).

Аналіз актуальних досліджень. Наукові дослідження з актуальних питань підготовки фахівців із фізичної терапії висвітлено в результатах досліджень таких учених, як О. М. Вацеба, А. М.Герцик, А. С. Вовканич, Т. Ю. Круцевич, А. В. Фастівець, В. П. Мурза, С. М. Попов - окремі аспекти клінічної діяльності фахівців із фізичної терапії; С. Ю Кобєлєв, С.ІІГородинський, О.І. Міхеєнко, Н.Я. Романішин, Г. Ю. Мороховець загальні питання професійної підготовки фахівців із фізичної терапії в закладах вищої освіти (Бєлікова, 2013, с. 19-25).

Канада $€$ одним із найвпливовіших членів Світової конфедерації фізичної терапії. Потреба в канадських спеціалістах даної галузі на ринку праці в економічно розвинених країнах світу за останні роки значно зросла (Ситник, 2017, с. 168).

Аналіз науково-методичної та спеціальної літератури засвідчив, що досвід професійної підготовки бакалаврів фізичної терапії в Канаді вивчали такі вчені, як Sinéad Patricia Dufour, Jeffery Gabrush, Andrea Passmore визначили, що фізична терапія (ФТ) $€$ п'ятою провідною професією в галузі охорони здоров'я Канади, у якій у 2012 році становило 18469 працівників, а в 2008 році кількість працюючих становила 16889 осіб, що складає приблизно 53 ФТ на 100000 канадців. Статистичні дані засвідчують, що в 2013 році збільшилася кількість працівників на 19,7\% порівняно з 2008 роком (Sinéad Patricia Dufour, 2011; Entry-to-Practice Physiotherapy Curriculum: Content Guidelines for Canadian University Programs, 2009).

Закордонний досвід професійної підготовки бакалаврів із фізичної терапії ретельно вивчав український дослідник А. М. Герцик - підготовка бакалаврів фізичної терапії в Канаді.

Таким чином, актуальність представленої теми полягає в необхідності реформування вітчизняних планів підготовки спеціалістів із фізичної терапії та можливості перенесення канадського досвіду до університетів та коледжів України (Olkhovyk, 2018).

Мета дослідження - визначення можливостей перенесення канадського досвіду з питань підготовки фахівців з фізичної терапії в університетах України.

Завдання дослідження: проаналізувати зміст професійної підготовки бакалаврів із фізичної терапії в медичних закладах Канади; дослідити можливості перенесення канадського досвіду з підготовки бакалаврів 3 фізичної терапії для підготовки фахівців фізичної терапії в Україні. 
Методи дослідження: теоретичний аналіз науково-методичної літератури з питання професійної підготовки бакалаврів фізичної терапії в Канаді, навчальних планів, програм, синтез, порівняння, педагогічне спостереження.

Виклад основного матеріалу. Одним із головних завдань дослідження $\epsilon$ проведення порівняльно-педагогічного аналізу професійної підготовки фахівців із фізичної терапії в Канаді та Україні та можливості шляхів перенесення передового канадського досвіду до українських закладів освіти.

Під час проведення комплексного аналізу потрібно звернути особливу увагу на такі критерії: орієнтація освітніх програм, органи управління та контролю, форми та терміни навчання, практична підготовка, форми контролю, працевлаштування (Entry-to-Practice Physiotherapy Curriculum: Content Guidelines for Canadian University Programs, 2009).

Проведення досліджень із приводу професійної підготовки фізичних терапевтів в Україні показало, що в сучасних умовах студенти ЗВО недостатньою мірою володіють професійними знаннями, уміннями та навичками, також спостерігається відсутність навичок самостійної роботи, низька ініціативність, нездатність самостійно приймати рішення, невміння мислити критично, низька самодисципліна. Велика кількість працівників фізіотерапевтичних закладів і закладів соціального захисту населення недостатньо задоволена рівнем професійної підготовленості студентівпрактикантів (Белікова, 2012).

Фізіотерапевтична діяльність в Україні останнім часом продукує нові вимоги до фахівців даної спеціальності. Здатність працівників виконувати свої обов'язки професійно і в новому форматі вимагає від них певної освітньої кваліфікації. Специфічність цієї спеціальності полягає в тому, що спектр закладів, у яких може працювати фізичний терапевт, надзвичайно великий, сюди відносяться всі освітні установи, заклади охорони здоров'я, соціального захисту, громадські організації інвалідів (табл. 1). Тому майбутній фахівець із фізичної терапії має бути добре обізнаний у професійній сфері, бачити перспективи ії подальшого розвитку i вдосконалення (Entry-to-Practice Physiotherapy Curriculum: Content Guidelines for Canadian University Programs, 2009).

Згідно з програмами міжнародних організацій, а саме СКФТ, обов'язковим компонентом навчальних програм для студентів спеціальності фізична терапія $є$ проходження практики не менше ніж 1000 годин, однак у даний час не спостерігається виконання відповідних вимог у системі вітчизняної підготовки відповідних фахівців (Настанови світової конфедерації фізичної терапії для розвитку системи законодавства регулювання визначення професії фізичних терапевтів, 2012). 
Таблиця 1

Порівняльна характеристика систем підготовки бакалаврів спеціальності «Фізична терапія» в Україні та Канаді

\begin{tabular}{|c|c|c|}
\hline Назва критеріїв оцінки & $\begin{array}{c}\text { Система української } \\
\text { підготовки }\end{array}$ & $\begin{array}{c}\text { Система канадської } \\
\text { підготовки }\end{array}$ \\
\hline $\begin{array}{l}\text { Заклади } \\
\text { спеціальності }\end{array}$ & $\begin{array}{l}\text { В основному в закладах } \\
\text { вищої освіти фізкультурного } \\
\text { профілю, } \\
\text { фізичної культури та спорту, } \\
\text { факультети } \\
\text { культури }\end{array}$ & $\begin{array}{l}\text { Факультети наук про } \\
\text { здоров'я, Школи фізичної } \\
\text { терапії, } \\
\text { реабілітаційних наук }\end{array}$ \\
\hline $\begin{array}{l}\text { Кількість університетів, які } \\
\text { готують фахівців із фізичної } \\
\text { терапії }\end{array}$ & $\begin{array}{l}56 \text { (з них лише } 3 \text { заклади } \\
\text { медичного спрямування) }\end{array}$ & $\begin{array}{l}13 \text { (всі заклади медичного } \\
\text { спрямування) }\end{array}$ \\
\hline $\begin{array}{lll}\text { Органи } & \text { управління } \\
\text { контролю } & \end{array}$ & $\begin{array}{lcc}\text { «Закон України } & \text { про вищу } \\
\text { освіту» } & \text { від } & 01.07 .2014 \\
\text { передбачає автономію 3Во }\end{array}$ & $\begin{array}{l}\text { «Базовий навчальний план } \\
\text { канадських освітніх } \\
\text { програм з фізичної терапії» }\end{array}$ \\
\hline $\begin{array}{l}\text { Тривалість } \\
\text { студентів }\end{array}$ & 6 тижнів & 33 тижні \\
\hline Мова викладання & Державна & Англійська, французька \\
\hline Засоби н & \begin{tabular}{lr} 
Складання & тестового \\
ліцензійного іспиту «Крок- \\
1ФР» з 2020 року, а вданий \\
момент & -написання \\
кваліфікаційної & роботи, \\
складання & практично \\
орієнтованих & державних \\
іспитів із & дисциплін \\
\multicolumn{2}{l}{ професійної підготовки }
\end{tabular} & $\begin{array}{l}\text { Складання екзамену } \\
\text { компетенції у фізичній } \\
\text { терапії, що складається } 3 \\
\text { двох частин: письмової - } \\
\text { «Кваліфікаційний екзамен» } \\
\text { та практичної частини } \\
\text { (клінічної) - «Національним } \\
\text { екзаменом з фізичної } \\
\text { терапії» }\end{array}$ \\
\hline $\begin{array}{l}\text { Особливості } \quad \text { професійної } \\
\text { підготовки }\end{array}$ & $\begin{array}{lr}\text { Особистісний } & \text { та } \\
\text { компетентнісний } & \text { підходи, } \\
\text { принципи } & \text { демократії та } \\
\text { гуманізації } & \text { навчання, } \\
\text { поєднання } & \text { національних } \\
\text { традиції } & \\
\end{array}$ & $\begin{array}{l}\text { Використання } \\
\text { мультидисциплінарного } \\
\text { підходу та командного } \\
\text { принципу організації, } \\
\text { практико-орієнтований та } \\
\text { особистісний підходи }\end{array}$ \\
\hline $\begin{array}{l}\text { Форми організації } \\
\text { освітнього процесу }\end{array}$ & $\begin{array}{l}\text { - навчальні заняття; } \\
\text { - самостійна робота; } \\
\text { - практична підготовка; } \\
\text { - контрольні заходи }\end{array}$ & $\begin{array}{l}\text { - лекційні заняття; } \\
\text { - семінарські занятя; } \\
\text { - практичні заняття }\end{array}$ \\
\hline Вартість навчання & 6-12 тис. за рік & 8000 \$ за рік \\
\hline Термін навчання & 4 років & 4-6 pp. \\
\hline Форма навчання & Денна та заочна & $\begin{array}{l}\text { Денна, заочна } \\
\text { дистанційна }\end{array}$ \\
\hline Освітні рівні & $\begin{array}{l}\text { Бакалавр (4 роки), магістр } \\
\text { (1,5-2 роки) }\end{array}$ & $\begin{array}{l}\text { Бакалавр (4 роки), магістр } \\
\text { (2 роки) }\end{array}$ \\
\hline
\end{tabular}

Практична підготовка канадських фахівців має суттєві відмінності, а came: 
- студенти повинні проходити практику кожного семестру;

- проходження не менше ніж 1000 годин проходження практики дає випускникові право на подальшу професійну діяльність;

- обов'язковим для всіх студентів $\epsilon$ проходження практики в сільській місцевості;

- невелика кількість студентів закріплена за одним викладачем (один або два студенти, принцип 1:2) (McJunkin, T., Swing, E., Walters, K., Lynch, P., 2017).

Оцінювання проходження практики здійснюється відповідно до спеціальних стандартів, які розроблюються кожним університетом. У системі українських закладах освіти немає окремих вимог, оцінки практичної діяльності студентів. В основному контроль здійснюють керівники організацій, де проходить практика, які не завжди $\epsilon$ зацікавленими в додатковому навантаженні студентів, а отже, такий контроль носить формальний характер. Удосконалення вмінь та навичок більшою мірою залежить від усвідомлення студентом важливості практичного навчання (Entry-to-Practice Physiotherapy Curriculum: Content Guidelines for Canadian University Programs, 2009).

у сучасних умовах в Україні для спеціалістів «Фізична терапія» особливо актуальним питанням є проблеми з працевлаштуванням за своєю спеціалізацією, в основі розв'язання даної проблеми $€$ підготовка фахівців даної спеціальності, яка ведеться в основному в закладах освіти немедичного спрямування. Тому в подальшому у вітчизняній системі підготовки фахівців слід звернути увагу на канадський досвід із питань правового регулювання даної проблеми, адже в даній країні професія ФТ має правовий статус (Мордвінова та Ольховик, 2018, с. 152-161; Осіпов, 2013, с. 131-136).

Ще однією важливою перевагою є мультидисциплінарній підхід, що базуються на досягненні спільної мети, під час використання різних циклів дисциплін та командного принципу організації, що суттєво прискорює проведення лікувально-реабілітаційних заходів хворих та інвалідів. Перевагами в роботі в складі команди $€$ колективна відповідальність у досягненні спільної мети, взаємозв'язок та взаємодоповнення. Адже командний принцип є однією з відмінних рис системи надання допомоги людям із обмеженими можливостями (Лянной, 2017).

Вартість навчання у вітчизняних $3 В 0 €$, безперечно, нижчою, ніж у Канаді, проте слід зазначити, що рівень заробітної плати в даній галузі не співвідноситься під час порівняння цих двох країн. Для отримання ступеня бакалавра ФТ в Україні потрібно сплатити 6- 12 тис. за рік, за рік навчання в Канаді - 8000\$ (Master of Physical Therapy (M PT) Program. Frequently Asked Questions , 2013).

Слід зазначити, що українські студенти навчаються за більш узагальненою програмою, ніж канадські студенти, які отримують освіту за 
більш вузькою програмою, де кожна дисципліна взаємопов'язана саме 3 фаховою спеціалізацію і тісно переплітається одна з одною (Entry-to-Practice Physiotherapy Curriculum: Content Guidelines for Canadian University Programs, 2009). У системі української підготовки програма охоплює не лише професійну, але й академічну вищу освіту, що має на меті всебічний розвиток майбутніх фахівців із ФТ. Проте велика кількість загальнообов'язкових дисциплін вважається недоцільною, оскільки студенти даної спеціалізації потребують більшою мірою практичної підготовки (Гус, 2015).

Ще одним суттєвим недоліком вітчизняної системи підготовки фахівців із ФТ є обмеженість студентів самостійно обирати дисципліни для вивчення.

У цьому питанні заклад самостійно встановлює обов'язкові предмети, тому позитивним досягненням було би перенесення канадського досвіду де студентам надається більше прав у виборі навчальних предметів за бажанням (Core Standards of Practice for Physiotherapists in Canada, 2016).

Ще одним питанням, яке потребує уваги, це наявність інноваційних технологій у процесі навчання, які сприяють розвиткові клінічного мислення й пошукової діяльності студентів. В українській системі підготовки більшої мірою переважають традиційні способи проведення занять. Тобто, у системі підготовки канадських фахівців процес навчання менш регламентований, що дозволяє викладачу більшою мірою зосередитися на аналізі клінічних випадків та дискусії з студентами. Це забезпечується тим, що на лекційні заняття студенти приходять заздалегідь підготовлені, що не спостерігається у вітчизняних 3ВО (Lekkas et al., 2007).

У процесі порівняльного аналізу було виокремлено як спільні, так і відмінні ознаки цих країн, з'ясовано, що підготовку бакалаврів з ФТ проводять у 56 закладах вищої освіти України, з яких лише 3 заклади медичного спрямування, що $є$ значною проблемою випускникам під час працевлаштування, також спостерігається значна відмінність у кількості відведених годин практики та інноваційних технологій у процесі навчання.

Висновки та перспективи подальших наукових розвідок. Вивчено та досліджено зміст професійної підготовки бакалаврів із фізичної терапії в медичних закладах Канади. Було проаналізовано «Базовий навчальний план канадських освітніх програм з фізичної терапії», який є основою для закладів освіти, які готують фахівців з ФТ, згідно з яким підготовка бакалаврів здійснюється за безперервною 36-місячною програмою, що складається з 5 блоків фундаментальних і спеціальних дисциплін та 1000 годин клінічної практики. Клінічна практика складається з п'яти блоків: РТ Movement Sciences, РT Therapeutics, Cardiorespiratory PT Practice, Musculoskeletal PT Practice and Neurological PT Practice. Розглянуто шляхи перенесення канадського досвіду до вітчизняної системи підготовки спеціалістів даної галузі. Під час розробки навчальних планів зі 
спеціальності «Фізична терапія» у ЗВО України має звертися особлива увага на зміст канадських навчальних програм з фізичної терапії, тривалість занять базових предметів та співвідношення теоретичних і практичних знань та навичок у «національному екзамені з фізичної терапії».

\section{ЛІТЕРАТУРА}

Бєлікова, Н. (2013). Змістове наповнення процесу підготовки майбутніх фахівців із фізичної реабілітації до здоров'язбережувальної діяльності. Фізичне виховання, спорт і культура здоров'я у сучасному суспільстві, 4 (24), 19-25 (Bielikova, N. (2013). Content of the preparation process for future specialists in physical rehabilitation for health-saving activities. Physical education, sports and health culture in modern society: a collection of scientific works, 4 (24), 19-25).

Бєлікова, Н. О. (2012). Теоретичні і методичні засади підготовки майбутніх фрахівців з фрізичної реабілітації до здоров'язбережувальної діяльності (автореф. дис... дра пед. наук). Київ (Bielikova, N. A. (2012). Theoretical and methodological principles for the preparation of future specialists in physical rehabilitation for health-saving activities (DSc thesis abstract). Kyiv).

Бісмак, О.В. (2016). Клінічна діяльність фахівців з фізичної реабілітації в Україні: проблеми та перспективи. Освітологічний дискурс, 3 (15), 338-351 (Bismak, O.V. (2016). Clinical activity of specialists in physical rehabilitation in Ukraine: problems and prospects. Educational discourse, 3 (15), 338-351).

Гук, С. В. (2015). Профресійна підготовка фрахівців з фізичної реабілітації в університетах Великої Британії (дис. ... канд. пед. наук). Кам'янецьПодільський (Huk, S. V. (2015). Professional training of specialists in physical rehabilitation at universities in the UK (PhD thesis). Kamianets-Podilskyi).

Лянной, Ю.О. (2017). Теоретичні і методичні засади професійної підготовки майбутніх магістрів з фізичної реабілітації у вищих навчальних закладах (автореф. дис. ... д-ра пед. наук). Київ (Liannoi, Yu. О. (2017). Theoretical and methodological foundations of professional training of future masters in physical rehabilitation in higher educational establishments (DSc thesis abstract). Kyiv).

Мордвінова, І., Ольховик, А. (2018). Підготовка студентів спеціальності «Фізична терапія» та «Ерготерапія» у країнах Європи. Педагогічні науки: теорія, історія, інновачійні технології, 1 (75), 152-161. doi: http:10.24139/23125993/2018.01/152-161 (Mordvinova, I., Olkhovik, A. (2018). Preparation of students of the specialty "Physical Therapy" and "Ergotherapy" in Europe. Pedagogical sciences: theory, history, innovative technologies, 1 (75), 152-161. doi: http:10.24139/2312-5993/2018.01/152-161).

Настанови світової конфедерації фізичної терапії для розвитку системи законодавства регулювання визначення профресії фізичних терапевтів (2012). Львів (Guidelines of the World Confederation of Physical Therapy for the Development of Legislation for the Regulation of the Definition of the Profession of Physical Therapists (2012). Ukrainian Association of Physical Therapy. Lviv).

Осіпов, В. А. (2013). Особливості професійної підготовки майбутніх фахівців з фізичної реабілітації, спортивної медицини та адаптивного фізичного виховання. Актуальні проблеми фрізичної реабілітації, спортивної медицини та адаптивного фізичного виховання, 3, 131-136 (Osipov, V. А. (2013). Features of professional training of future specialists in physical rehabilitation, sports medicine and adaptive physical education. Actual problems of physical rehabilitation, sports medicine and adaptive physical education, 3, 131-136). 
Приступа, Є. Н., Вовканич, А. С. (2011). Роль і місце фахівця з фізичної реабілітації в системі охорони здоров'я населення. Педагогіка, психологія та медикобіологічні проблеми фрізичного виховання і спорту, 9, 92-96 (Prystupa, E. N, Vovkanych, A. S. (2011). The role and place of a specialist in physical rehabilitation in the public health system. Pedagogy, psychology, medical and biological problems of physical education and sports, 9, 92-96).

Ситник, О., Степаненко, О. (2017). Практична підготовка фізіотерапевтів в медичних ВН3. здоров'я людини: теорія і практика: матеріали Міжнародної науково-практичної конферениії, присвяченої 25-річчю Медичного інституту Сумського державного університету (м. Суми 17-19 жовтня 2017 р.). Суми: СумДУ, С. 168-170 (Sytnyk, 0., Stepanenko, 0. (2017). Practical training of physiotherapists in medical universities. Human health: theory and practice: materials of the International scientific and practical conference devoted to the 25th anniversary of the Medical Institute of Sumy State University, (October 17-19, 2017). Sumy, pp. 168-170).

Core Standards of Practice for Physiotherapists in Canada. May, 2016. Retrieved from: https:// www.manitobaphysio.com/wp-content/uploads/Core-Standards-of-

Practice-Final-05.05.16-002.pdf.

Sinéad Patricia Dufour (2011). Understanding the Roles of Physiotherapists Within Ontario Primary Health Care Teams: A Mixed Methods Inquiry. Electronic Thesis and Dissertation $\quad$ Repository, Retrieved from: https:// ir. lib.uwo.ca/ cgi/ view content.cgi?article=1499\& context=etd.

Entry-to-Practice Physiotherapy Curriculum: Content Guidelines for Canadian University Programs (2009). Council of Canadian Physiotherapy University Programs. Retrieved from: http://www.physiotherapyeducation.ca/Resources/National\%20PT\%20Curricul um\%20Guidelines\%202009.pdf.

Lekkas, P., Larsen, T., Kumar, S. (2007). No model of clinical education for physiotherapy students is superior to another: a systematic review. Australian Journal of Physiotherapy. Australian, 53, 19-28. doi: // org/10.1016/S0004-9514(07)70058-2.

Master of Physical Therapy (MPT) Program. Frequently Asked Questions (2013). Faculty of Medicine. School of Medical Rehabilitation Department of Physical Therapy. Retrieved from: http://umanitoba.ca/rehabsciences/media/pt_faq_mpt.pdf.

M cJunkin, T., Swing, E., Walters, K., Lynch, P. (2017). M ultidisciplinary Pain Management in the Rehabilitation Patient. Springer International Publishing. Retrieved from: https:// www.springer.com/cda/content/document/cda downloaddocument/978331 9167831-c1.pdf?SGWID=0-0-45-1611102-p177304696.

Olkhovyk, A., Shepil, A. (2018). Foreign experience of preparation of bachelors of physical therapy in medical establishments of Canada. Topical issues of theoretical and clinical medicine: abstract book of International scientific and practical conference of students, postgraduates and young scientists, October 17-19, 2018. Sumy.

\section{PEЗЮME}

Мордвинова Инна, Ольховик Алина. Сравнительная характеристика системы подготовки бакалавров специальности «Физическая терапия» в Украине и Канаде.

В статье освещена профессиональная подготовка бакалавров специальности «физическая терапия» в Украине и Канаде. Данная специальность требует от будущих специалистов комплексного подхода при осуществлении своей профессиональной деятельности. Специалист по физической терапии должен компетентно уметь проводить реабилитационное обследование, осуществлять анализ полученных данных, устанавливать реабилитационный диагноз, проводить реабилитационные мероприятия и оценку их эфрфективности, работать $в$ 
мультидисциплинарной команде. Доказано, что отечественная модель подготовки имеет отличия от канадской модели, основанные на принципах организации, финансирования, профрессионального этикета, самодисциплины специалистов в отличие от канадской, где за основу взят мультидисциплинарный подход.

Ключевые слова: физическая терапия, студент, программы, профессиональная подготовка, физиотерапевтическая деятельность, мультидисциплинарный подход.

\section{SUMMARY}

Mordvinova Inna, Olkhovyk Alina. Comparative characteristics of the system of training bachelors of the specialty "physical therapy" in Ukraine and Canada.

The article reveals professional training of bachelors of the specialty "physical therapy" in Ukraine and Canada. This specialty requires from future specialists of a comprehensive approach in carrying out their professional activities. Physical therapy specialist should be competent to conduct physiotherapy examination, to analyze the data obtained, to establish physiotherapy diagnosis, to carry out physiotherapy measures and evaluation of their effectiveness, to work in a multidisciplinary team. It is proved that domestic model of training differs from the Canadian model, which is based on the principles of organization, financing, professional etiquette, self-discipline of specialists, unlike the Canadian one, which is based on a multidisciplinary approach.

it is proved that in the era of global social, economic and demographic crisis, the issue of the level of health of the population, its preservation and improvement, which is now a medico-social problem that needs immediate solution, is especially urgent, so recently there is a need to improve organization of the national systems for training future specialists in physical therapy.

An analysis of the scientific-methodological and specialized literature has shown that experience of professional training of bachelors of physical therapy in Canada has been studied by such scientists as Sinéad Patricia Dufour, Jeffery Gabrush, Andrea Passmore. They have determined that physical therapy is the fifth leading profession in the field of health care in Canada, which in 2012 had 18469 employees and in 2008 the number of employees was 16 889, which is approximately $53 \mathrm{ft}$ per 100,000 Canadians. Statistics show that in 2013, the number of employees increased by $19,7 \%$ compared to 2008 .

Thus, relevance of the presented topic lies in the need to reform national plans for training physical therapy specialists and the possibility of transferring Canadian experience to universities and colleges of Ukraine.

The purpose of the study is to determine the possibilities of transferring Canadian experience in the field of training specialists in physical therapy at universities in Ukraine.

Objectives of the study: to analyze the content of professional training of bachelors in physical therapy in medical institutions in Canada; explore the potential of transferring Canadian Bachelor of Physical Therapy training experience to training physical therapy professionals in Ukraine.

Research methods: theoretical analysis of scientific and methodological literature on professional training of Bachelor of Physical Therapy in Canada, curricula, programs, synthesis, comparison, pedagogical observation.

The content of the Bachelor's Degree in Physical Therapy at Medical Institutions of Canada has been studied. The Basic Curriculum for Canadian Physical Therapy Educational Programs has been analyzed, which is the basis for education institutions that train PT specialists, according to which preparation of bachelors is carried out under a continuous 36month program consisting of 5 blocks of basic and special disciplines and 1000 hours of clinical practice. Clinical practice consists of five blocks: PT Movement Sciences, PT 
Therapeutics, Cardiorespiratory PT Practice, Musculoskeletal PT Practice, and Neurological PT Practice. The ways of transfer of Canadian experience to the national system of training of specialists in this field are considered.

Key words physical therapy, student, programs, vocational training, physiotherapy, multidisciplinary approach.

удк 37.017 .4

Тетяна Пахотіна

Сумський державний педагогічний університет імені А. С. Макаренка ORCID ID 0000-0002-5132-4326

DOI 10.24139/2312-5993/2020.02/285-292

\section{ПАТРІОТИЧНЕ ВИХОВАННЯ ЯК ПРЕДМЕТ ПОРІВНЯЛЬНО-ПЕДАГОГІЧНИХ ДОСЛІДЖЕНЬ}

у статmі з'ясовано сутність патріотичного виховання як предмету порівняльно-педагогічних досліджень. З'ясовано, що патріотизм являє собою моральну основу життездатності держави, важливий внутрішній мобілізуючий ресурс, що базується на активній громадянській позиції особистості, їі готовності самовіддано служити своїй Вітчизні. Патріотизм виявляється в практичній діяльності, спрямованій на всебічний розвиток своєї країни, захист ії інтересів. Виховання патріотизму є важливою складовою виховної діяльності школи.

Ключові слова: патріотизм, патріотичне виховання, порівняльно-педагогічні дослідження, Україна, Польща.

Постановка проблеми. Патріотизм як моральна цінність та сукупність соціально-політичних відносин є потужним фактором і необхідною умовою для захисту національних інтересів, відродження та зміцнення української нації. В умовах нинішньої економічної, соціальної, духовної та культурної кризи особливої актуальності набуває необхідність патріотичного виховання підростаючого покоління. Розвиток гострої конкуренції соціально-орієнтованих цінностей та гедоністичних ідеалів на рівні масової свідомості, неможливість повної реалізації потреб, нав'язаних мас-медіа, викликає зміни на духовному рівні, викривлення системи цінностей. Незбалансованість соціальних реформ призвела до розповсюдження в суспільстві таких негативних оціночних та поведінкових стереотипів, як громадянський інфантилізм, індивідуалізм та егоїзм, що, у свою чергу, спричинило падіння довіри до державних та правових інститутів. Одним із проявів кризової деформації свідомості $€$ ціннісний колапс, а особливої трансформації зазнають патріотичні почуття молодих людей. Необхідність цілеспрямованої державної політики у сфері національно-патріотичного виховання молоді зумовлена потребою консолідації всього українського суспільства для подолання викликів, що постали перед країною. За умов кризового стану соціуму та гострої конфліктної ситуації актуалізується необхідність дослідження ефективності реалізації державної політики у сфері національно-патріотичного виховання. 